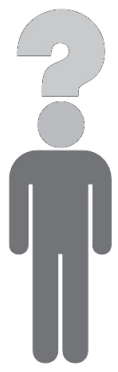

\title{
USTAWA O DZIAŁALNOŚCI LOBBINGOWEJ W PROCESIE STANOWIENIA PRAWA A SPOŁECZEŃSTWO ODPOWIEDZIALNE
}

Celem niniejszego artykułu jest analiza Ustawy z dnia 7 lipca 2005 r. o działalności lobbingowej w procesie stanowienia prawa (Dz. U z 2005 r. Nr 169 poz. 1414) i jej konfrontacja z zaproponowaną konstrukcją idei społeczeństwa odpowiedzialnego, społeczeństwa odpowiedzialności. Działalność lobbingowa to ważny i złożony temat dotykający kwestii grup interesu, reprezentowania tych interesów, funkcjonowania najważniejszych organów władzy państwowej dotyczący najważniejszej działalności w politycznej wspólnocie, jaką jest stanowienie prawa. Przedmiotowa ustawa reguluje proces stanowienia prawa. Zawiera więc - tak jak konstytucja - reguły tworzenia reguł. Jest to ustawa o tworzeniu innych ustaw - bardzo wrażliwe i niezmiernie ważne zagadnienie. W swoim artykule nie koncentruję się na samym zjawisku grup interesu, lecz nad ustawą regulującą wpływanie owych grup na proces stanowienia prawa.

Nadmienię tylko kilka powodów, dla których zagadnienie lobbingu jest kwestią wysoce problematyczną, a nawet kontrowersyjną. Pierwszym powodem jest funkcjonowanie zjawiska określonego przez Miltona Friedmana jako „żelazny trójkąt" utrzymujący "tyranię status quo". Tyrania ta stanowi mechanizm powstrzymywania korzystnych zmian w państwie i w jego systemie prawa. $\mathrm{Na}$ ów trójkąt składają się: reprezentanci grup interesów, politycy i biurokraci ${ }^{1}$. Kolejną przyczyną jest fakt, że grupa interesu jest zawsze mniejszością w danym społeczeństwie. Oczywiste jest, że większość obywateli (niemal wszyscy) nie należy do danej grupy interesu. Konfiguracja ta powoduje, że „program rządowy [...] prawie zawsze daje znaczne korzyści relatywnie małej grupie, rozkładając

1 M. Friedman, R. Friedman, Tyrania status quo, Sosnowiec 1997, s. 49. 
równocześnie koszty na ogół populacji (wskutek czego wydają się one niewielkie)"2. A zatem w interesie społeczeństwa nie leży kierowanie się celami grup interesu. Możemy zatem przyjąć, że kierowanie się racją stanu to kierowanie się interesem swoistego „everymana” - przeciętnego obywatela, nieposiadającego żadnej cechy specyficznej - która włączałaby go do jakiejś mniejszości - grupy interesu. Niemniej jednak grupy interesu działają i wpływają na stanowienie prawa, o czym świadczy chociażby obowiązywanie analizowanej ustawy. Z faktu, że ta ustawa obowiązuje, wynika, że interesy grupowe mogą być reprezentowane. Przyjmijmy więc, że tak jest, i skupmy się na zagadnieniu, co i jak zostało uregulowane, oceniając to przez pryzmat idei odpowiedzialnego społeczeństwa.

Na wstępie należy przedstawić pewne zastrzeżenie metodologiczne specyficzne dla nauk społecznych. Otóż aby przeanalizować kategorię społeczeństwa odpowiedzialnego i właściwie uprawiać nauki społeczne, należy pamiętać o podstawowym założeniu metodologicznym indywidualizmu. Mówi nam ono o tym, że działają wyłącznie jednostki ludzkie (społeczeństwo czy państwo nigdy nie działa i nie zachowuje się) ), doświadczyć możemy tylko działania jednostek ludzkich i to w ich małej liczbie, resztę konstruujemy, domyślamy się relacji, schematów. Jeśli mówimy o jakimś procesie świadomym (a żeby być odpowiedzialnym i ponieść odpowiedzialność, trzeba być świadomym) - to oznacza, że mówimy tu o sterowaniu przez jednostkę ludzką; jeśli mamy do czynienia z procesem społecznym, to z definicji jest on nieświadomy ${ }^{4}$. A zatem samo sformułowanie „społeczeństwo odpowiedzialne” jest pewną metaforą. Jeśli chcemy ocenić, czy mamy do czynienia ze społeczeństwem odpowiedzialnym, musimy ocenić działanie reprezentantów społeczeństwa wybranych w ramach instytucji demokracji przedstawicielskiej, a także innych jednostek sprawujących władzę oraz przede wszystkim instytucje społeczne i polityczne, które mają urzeczywistnić wartości indywidualne i wspólnotowe, które składają się na konstrukcję społeczeństwa odpowiedzialnego. Możemy więc, myśląc o „społeczeństwie odpowiedzialnym”, ocenić działanie nielicznych jednostek odpowiedzialnych za władzę w danej wspólnocie albo instytucji, które regulują działania wszystkich jednostek w tej wspólnocie.

\footnotetext{
Tamże, s. 41.

F. A. von Hayek, Nadużycie rozumu, Warszawa 2002, s. 32, przyp. 12.

Tamże, s. 81.
} 
W tym miejscu ważne jest też podkreślenie pewnej podstawowej kwestii, zakrawającej wręcz na truizm. Truizm ten jest jednak na tyle ważny dla końcowej oceny przedmiotowej ustawy, że i on musi być tu wyrażony. Otóż ważna jest świadomość tego, że stanowienie prawa jest racjonalną działalnością, mającą na celu uregulowanie specyficznego, „żywego” systemu społecznego. Ustawa jest narzędziem, które ma przynosić zakładane efekty. Ustawa jest tworem celowym, jest stworzona po coś, jest stworzona, by urzeczywistnić pewien cel. Nie jest tak, że celem jest samo istnienie ustawy. Nie reguluje się kwestii dla samej regulacji, a dla konkretnych instrumentów, przynoszących zakładane, korzystne rezultaty. Nie tworzy się ustawy o dobrobycie, ustawy likwidującej biedę czy ustawy o pomyślności, nie tworzy się ustawy o dobrym funkcjonowaniu społeczeństwa. Ustawa ma tworzyć konkretne instytucje, które mają posłużyć realizacji celów. Ustawa nie jest dobrem samym w sobie, a jedynie dobrem ze względu na instrumenty, które daje, jeśli je daje.

$Z$ tego powodu pomocna (lecz nie wystarczająca) do analizy przedmiotowej ustawy, jak i w ogóle do analizy systemu prawa, jest perspektywa cybernetyczna. Takie ujęcie ma podkreślić, że ustawa jest celowościowa, że jest pewną informacją wysyłaną przez organizatorów do systemu, która ma wywołać pożądany efekt. Dlatego nie wchodząc w podstawowe filozoficzne spory o ontologię prawa, można w pewnym wymiarze posłużyć się analizą systemową prawa, cybernetyką socjologiczną. W tym ujęciu możemy spoglądać na społeczeństwo i jego instytucje jak na pewien układ zorganizowany z wysyłanymi bodźcami i komunikatami na temat reakcji na te bodźce, które to komunikaty stanowią kolejne bodźce $^{5}$. I tak władza wysyła bodźce w postaci norm prawnych, które mają swoje skutki w społeczeństwie. Przyjęcie perspektywy cybernetycznej nie kłóci się z wyżej wymienionym zastrzeżeniem metodologicznym indywidualizmu, ponieważ $w$ tej perspektywie będziemy pozostawali na poziomie układu, jakim jest całe społeczeństwo i jego instytucje czy też informacje, jakimi są ustawy. Unikniemy tym samym wnikania w psychologię społeczną czy przekładania ocen systemu na oceny ludzi i odwrotnie. Możemy więc dzięki takiemu ujęciu poprzestać na badaniu tego, jaka informacja zostaje wysłana, jak się ma to do zakładanego celu i jaka jest reakcja społeczeństwa na tę informację. Jak pisali państwo Friedmanowie: ,jak już stwierdziliśmy, rozważając jedną dziedzinę polityki

5 J. Kossecki, Cybernetyka kultury, Warszawa 1974, s. 36. 
za drugą, kwestię stanowią tu bodźce" ${ }^{\prime}$. Takie ujęcie pozwala nam nie skupiać się na przyczynach zjawisk zachodzących w społeczeństwie, na swego rodzaju „psychoanalizie społecznej”, lecz na celu systemu - wspólnoty - i metodzie jego osiągnięcia?.

Wspomniałem wyżej o pewnych wartościach, które składają się na konstrukcje odpowiedzialnego społeczeństwa. Mówiąc o społeczeństwie odpowiedzialnym, społeczeństwie odpowiedzialności, mamy na myśli także pewne wymagania stojące przed jego organizacją i funkcjonowaniem. Pamiętając o zastrzeżeniu metodologicznym indywidualizmu, możemy spróbować przedstawić taką listę wartości i wymagań. Pomocne w tym celu będzie uświadomienie sobie, że na poziomie jednostki mówimy, że jest ona odpowiedzialna lub ma zdolność ponoszenia pełnej odpowiedzialności w sytuacji, gdy osiągnie ona odpowiedni stopień dojrzałości. Możemy więc powiedzieć, że odpowiedzialność jest funkcją dojrzałości. A zatem jeśli chcemy określić, jakie wartości stoją u podstaw społeczeństwa odpowiedzialnego, musimy mieć w głowie obraz dojrzałej jednostki oraz to, co stanowi o jej dojrzałości i poprzez analogię przełożyć to na poziom społeczeństwa - jednostek sprawujących władzę oraz norm regulujących wspólnotę. Możemy teraz wymienić pewne warunki bycia dojrzałym. Po pierwsze więc, dojrzałość zakłada rozpoznanie swoich interesów. Człowiek to istota rozumna, odróżniająca dobro i zło, a więc jest to istota interesu, co może być wyrażone także przez stwierdzenie, że człowiek to homo oeconomicus, jego celem jest urzeczywistnienie swoich interesów. Jeśli już człowiek odróżnia dobro od zła, to jego interesem będzie wybór dobra.

Zakładamy, że człowiek jest homo oeconomicus, tj. wybiera takie działania, które maksymalizują jego funkcję użyteczności (element formalny koncepcji homo oeconomicus), oraz jest egoistą, tj. główny motyw jego zachowania stanowi troska o pomnażanie własnego dobra (element materialny koncepcji homo oeconomicus) ${ }^{8}$.

Każde działanie człowieka związane jest z realizacją jakiś celów - najlepiej jeśli są to jego własne cele. W kategorie ludzkiego działania wpisana jest kategoria interesu będącego realizacją celu tego działania. To samo dotyczy stanowienia prawa. Na tym poziomie ustawodawca, dokonując swych działań w po-

\footnotetext{
M. Friedman, R. Friedman, Tyrania status quo, dz. cyt., s. 93.

J. Kossecki, Cybernetyka kultury, dz. cyt., s. 7.

J. Stelmach, B. Brożek, W. Załuski, Dziesięć wykładów o ekonomii prawa, Warszawa 2007, s. 51.
} 
staci tworzenia norm prawnych, realizuje interes swojej wspólnoty. Po drugie, dojrzałość oznacza wpływanie na rzeczywistość poprzez własne, wolne działania. Niewątpliwie aby przypisać komuś odpowiedzialność za jakieś działania, muszą one być po pierwsze jego działaniami, po drugie muszą być dokonane w warunkach umożliwiających powzięcie decyzji o takim czy innym działaniu. Stan taki możemy nazwać wolnością, nie wchodząc w głębsze analizy z pogranicza psychologii i neurobiologii na temat tego, czy wolność powzięcia decyzji w ogóle istnieje, czy może też zawsze jesteśmy więźniami uwarunkowań. Dojrzałość, a zatem i odpowiedzialność, wymagają przyjęcia, że mamy wpływ na własne działania (a jeśli tak nie jest - dążenia do takiego stanu), że jesteśmy wolni w ich podejmowaniu. Po trzecie, dojrzałość to mierzenie się z konsekwencjami swoich działań, co oznacza, że przyjmujemy skutki naszych działań za swoje oraz że pod wpływem tych skutków będziemy w ten czy w inny sposób zmieniali rzeczywistość. Widzimy więc, że w kategorie dojrzałości, a więc odpowiedzialności, wpisane są świadomość, zrozumienie oraz wolność. W naszym przypadku, kiedy chcemy przyłożyć te kryteria do poziomu społeczeństwa, musimy ocenić, czy reprezentanci naszego społeczeństwa dokonują wolnych działań, realizujących interesy polskiego państwa, co nazywamy kierowaniem się racją stanu, oraz czy instytucje wytworzone $w$ danym porządku społecznym umożliwiają swobodne realizowanie indywidualnych interesów obywateli i realizowanie poprzez państwo interesów wspólnotowych.

$W$ analizie socjocybernetycznej założeniom tym odpowiada ujmowanie społeczeństwa jako zorganizowanego układu samodzielnego, w którym zachodzą procesy sterowania, polegające na wywieraniu pożądanego wpływu na określone zjawiska. Użycie terminu „pożądany” oddaje to, że każdy proces sterowniczy odbywa się w czyimś interesie, a więc że jest nierozerwalnie związany z jego celem i motywacją ${ }^{9}$. Specyfika układu samodzielnego (a więc także społeczeństwa) polega na tym, że w ramach jego struktury istnieje ośrodek sterowania (ustawodawca), który dokonuje procesów sterowniczych w interesie układu samodzielnego. Celem sterowania w układzie samodzielnym jest utrzymanie równowagi funkcjonalnej, co ma zapewnić kontynuowanie stanu samodzielności układu ${ }^{10}$. Tym samym, państwo (ośrodki władzy) poprzez działania sterowni-

\footnotetext{
9 J. Kossecki, Cybernetyka kultury, dz. cyt., s. 6.

10 Tamże, s. 73.
} 
cze odbywające się na zasadzie sprzężeń zwrotnych wysyła bodźce (ustawy) do społeczeństwa celem zapewnienia mu stabilności i samodzielności.

Pytanie, jakie należy sobie teraz postawić, to - czy możemy mierzyć jakoś odpowiedzialność społeczeństwa. Analiza systemowa pozwala ocenić, czy system funkcjonuje sprawnie, czy system samodzielny poprzez swoje ośrodki sterownicze zapewnia równowagę funkcjonalną - samodzielność i stabilność. Czy istnieją jednak jakieś parametry ilościowe, które ułatwiają nam poradzenie sobie z kwestią odpowiedzialności społeczeństwa i wskazanie jej stopnia? Możemy mierzyć wskaźniki wolności gospodarczej oraz parametry ilościowe funkcjonowania wymiaru sprawiedliwości - bo jest to jedno z podstawowych i najważniejszych zadań stojących przed organizacją państwową. Możemy sprawdzać kondycję wojska polskiego, bo jest to instytucja, której celem jest zdanie testu na największą odpowiedzialność - czyli zachowanie "fizycznej" suwerenności państwowej. Możemy wreszcie (i to stanowi pewien wskaźnik poziomu odpowiedzialność społeczeństwa) mierzyć kapitał społeczny - coś bardziej powszechnego i uniwersalnego, przenikającego funkcjonowanie całego społeczeństwa, na które składają się także wyżej wymienione elementy. Filarami stanowiącymi łącznie o kapitale społecznym są:

- wspólne wartości,

- zaufanie,

- zaangażowanie.

Za Czapińskim możemy przyjąć, że kapitał społeczny rozumiemy jako sieci społeczne regulowane normami moralnymi lub zwyczajem (a nie lub nie tylko - formalnymi zasadami prawa), które wiążą jednostkę ze społeczeństwem w sposób umożliwiający jej współdziałanie z innymi dla dobra wspólnego ${ }^{11}$. Korespondująca z analizą cybernetyczną jest koncepcja kapitału społecznego Jamesa Colemana, który wyróżnia trzy formy kapitału społecznego: 1) zobowiązania, oczekiwania i zaufanie sprzyjające uzyskaniu pomocy od innych osób, 2) kanały informacyjne i dostęp do informacji oraz 3) normy i efektywne sank$c^{12} e^{12}$. Jak już wspomniałem wcześniej, kapitał społeczny jest parametrem mie-

11 J. Czapiński, Kapitał ludzki i kapitał społeczny a dobrobyt materialny. Polski paradoks, http:// www.msap.uek.krakow.pl/doki/publ/Zarzadzanie_Publiczne_2008_2-4.pdf, s. 8 (30.06.2014).

12 J. Coleman, Social capital in the creation of human capital, „The American Journal of Sociology" vol. 94 (1988), [za:] D. Batorski, Kapitał społeczny i otwartość jako podstawa innowacyjności, https://www.academia.edu/2939443/Kapital_spoleczny_i_otwartosc_jako_podstawa_innowacyjnosci, s. 85 (30.06.2014). 
rzalnym, który poprzez swoją obiektywizację może posłużyć do właściwej oceny odpowiedzialności społeczeństwa. Im wyższy kapitał społeczny, tym społeczeństwo bardziej odpowiedzialne. Kapitał społeczny pokazuje, jak łatwo jednostkom swobodnie działać we wspólnocie wartości, w jakim stopniu układ społeczny jest stabilny i czy łatwo jest zapewnić jego samodzielność. Kapitał społeczny jest więc funkcją odpowiedzialnego społeczeństwa.

Powszechnie wykorzystywanymi w badaniach miarami kapitału społecznego są zaufanie interpersonalne i dobrowolna przynależność do organizacji społecznych. Rzadziej uwzględnia się miary norm, postaw i zachowań społecznych (np. stosunku do mniejszości czy do demokracji, uczestnictwa w życiu politycznym i - szerzej publicznym, działań na rzecz dobra wspólnego $)^{13}$.

Należy też nadmienić, że zgodnie z badaniami Czapińskiego kapitał społeczny w Polsce pozostaje od początku transformacji systemowej na bardzo niskim poziomie ${ }^{14}$.

Zbadajmy teraz, czy w takim świetle uznamy, że ustawa o działalności lobbingowej przyczynia się do utrwalania społeczeństwa odpowiedzialności, a więc czy zwiększa kapitał społeczny, czy - zgodnie z pespektywą cybernetyczną - stanowi właściwe bodźce, przyczyniające się do zapewnienia samodzielności i równowagi funkcjonalnej układu zorganizowanego, jakim jest społeczeństwo, wreszcie czy realizuje swoje cele.

Na wstępie zauważmy, że samo obowiązywanie Ustawy o działalności lobbingowej w procesie stanowienia prawa jest informacją dla systemu społeczeństwa, że wpływ na proces stanowienia norm regulujących daną wspólnotę mogą mieć grupy interesu, a więc mniejszości realizujące swoje interesy. Wpływ ten, zgodnie z istnieniem takiej ustawy, jest aprobowany, usankcjonowany, zinstytucjonalizowany i legitymowany autorytetem państwa - ośrodków decyzyjnych. Ustawa ta stanowi więc wprost informację, że ustawodawca może nie kierować się racją stanu. Nie twierdzę, że bez istnienia takiej ustawy owe grupy interesu miałyby mniejszy wpływ na proces stanowienia prawa, ale że ustawa ta stanowi informację o aprobacie takiego procesu, a więc stanowi niepożądany bodziec. Jednak do pełnej oceny tej ustawy konieczne jest przyjrze-

\footnotetext{
13 J. Czapiński, Kapitał ludzki..., dz. cyt., s. 6.

14 Tamże, s. 5.
} 
nie się, jakie regulacje wprowadza, a więc jak ogranicza działalność lobbingową i jakie daje instrumenty.

Ustawa składa się z 24 artykułów podzielonych na 6 rozdziałów. Celem ustawy, zgodnie z art. 1., jest określenie zasad jawności działalności lobbingowej w procesie stanowienia prawa, zasad wykonywania zawodowej działalności lobbingowej, form kontroli zawodowej działalności lobbingowej oraz zasad prowadzenia rejestru podmiotów wykonujących zawodową działalność lobbingową. Widzimy więc, że ustawodawca zakłada, że korzystne dla systemu jest to, aby w pewnym zakresie działalność lobbingowa była jawna, ograniczona, kontrolowana i rejestrowana, oraz że uczyni to przedmiotową ustawą.

Ustawa w art. 2. 1. wprowadza definicję legalną lobbingu, według której działalnością lobbingową jest każde działanie prowadzone metodami prawnie dozwolonymi zmierzające do wywarcia wpływu na organy władzy publicznej w procesie stanowienia prawa. Mamy więc dwa wyróżniki działalności lobbingowej: zmierzanie do wywarcia wpływu na organy władzy publicznej w procesie stanowienia prawa oraz zgodność z prawem metod działania. Drugi wyróżnik jest wart uwagi, ponieważ ustawa reguluje działalność dozwoloną, co więcej, zgodnie z zasadą praworządności każda działalność obywatela wyraźnie niezakazana jest dozwolona. Tutaj mamy do czynienia z dodatkowym zastrzeżeniem, że ta działalność dozwolona jest zgodna z prawem. A więc z punktu widzenia obowiązywania systemu prawa w państwie praworządnym to zastrzeżenie jest niepotrzebne. Mówi jednak nam dużo o samej istocie działalności lobbingowej - często jest ona wbrew interesowi wspólnoty i ciężko odróżnić ją od przestępstw płatnej protekcji czy łapownictwa. Niemniej jednak mamy legalną definicję, która sugeruje, że aprobowana co do zasady działalność lobbingowa może być mylona z popełnianiem przestępstw. Ustawa w art. 2. 2. wprowadza też wyróżnienie zawodowej działalności lobbingowej, którą jest zarobkowa działalność na rzecz osób trzecich. A więc by uznać kogoś za zawodowego lobbystę, należy stwierdzić łącznie, że działania podejmowane przez tę osobę przynoszą mu dochód oraz że są one wykonywane na rzecz innych niż on sam podmiotów.

Przyjrzymy się teraz, jakie instrumenty wprowadza przedmiotowa ustawa, by urzeczywistnić zakładane cele ustawy. Otóż pierwszym instrumentem jest ustanowienie $w$ art. 3. obowiązku prowadzenia wykazu prac legislacyjnych przez Radę Ministrów, który udostępniany jest w Biuletynie Informacji Publicznej. Dzięki więc ustawie o działalności lobbingowej mamy zobowiązanie Rady Ministrów, by jej działalność była zaplanowana. Dziwne to miejsce w systemie 
prawa, niemniej jednak jest to rozwiązanie korzystne dla społeczeństwa. Ustawa w art. 7. daje możliwość każdemu zgłoszenia zainteresowania pracami, które obejmuje wyżej wymieniony wykaz. Zgłaszający zainteresowanie musi zadeklarować interes, który w odniesieniu do danej regulacji zamierza chronić, oraz rozwiązanie prawne, o którego uwzględnienie będzie zabiegać. W art. 8. tej ustawy mamy wprowadzoną instytucję wysłuchania publicznego w sprawie projektu ustawy, którego zasady określa regulamin sejmu. Art. 9. wprowadza instytucję wysłuchania publicznego w sprawie projektów rozporządzeń. Osoby zgłaszające zainteresowanie pracami nad projektami ustaw i rozporządzeń, a więc także lobbyści, mogą wziąć udział w wysłuchaniach publicznych. Mamy więc w ustawie o działalności lobbingowej wprowadzoną instytucje demokracji bezpośredniej. Ponownie musimy przyznać, że jest to budzące wątpliwości miejsce w systemie prawa. Kolejnym instrumentem, który tworzy poprzez art. 10. analizowana ustawa, jest jawny rejestr podmiotów wykonujących zawodową działalność lobbingową, do którego wpis jest odpłatny. Opłatę za wpis do rejestru uiszcza się, dokonując zgłoszenia. Opłata nie może przekroczyć 100 zł. Zgodnie z art. 12. zawodowa działalność lobbingowa może być wykonywana dopiero po uzyskaniu wpisu do rejestru.

Jak jednak analizowana ustawa reguluje samą działalność lobbingową, jakie (i na kogo) nakłada obostrzenia, uprawnienia, obowiązki i przywileje? Ustawa wprowadza w art. 14. uprawnienie zawodowych lobbystów do wykonywania swojej działalności także w siedzibie urzędu obsługującego organ władzy publicznej oraz wprowadza obowiązek kierownika tego urzędu zapewnienia podmiotom wykonującym zawodową działalność lobbingową wpisanym do rejestru dostępu do kierowanego przez siebie urzędu w celu umożliwienia właściwego reprezentowania interesów podmiotów, na rzecz których jest wykonywana ta działalność. Dodatkowym obowiązkiem spoczywającym na organach władzy publicznej jest wynikająca z art. 16. konieczność niezwłocznego udostępnienia w Biuletynie Informacji Publicznej informacji o działaniach podejmowanych wobec nich przez podmioty wykonujące zawodową działalność lobbingową wraz ze wskazaniem oczekiwanego przez te podmioty sposobu rozstrzygnięcia. Art. 16. 2. ponadto zobowiązuje kierowników urzędów obsługujących organy władzy publicznej do określenia szczegółowego sposobu postępowania pracowników podległego urzędu z podmiotami wykonującymi zawodową działalność lobbingową oraz z podmiotami wykonującymi bez wpisu do rejestru czynności z zakresu zawodowej działalności lobbingowej, o których 
to podmiotach, zgodnie z art. 17., organy władzy publicznej niezwłocznie informują na piśmie ministra właściwego do spraw administracji publicznej. Art. 18. ustawy tworzy kolejny obowiązek kierowników urzędów obsługujących organy władzy publicznej w postaci opracowywania raz w roku informacji o działaniach podejmowanych wobec tych organów przez podmioty wykonujące zawodową działalność lobbingową.

Zwróćmy uwagę na fakt, iż wszystkie te przejawy regulacji działalności lobbingowej dotyczą wyróżnionej w ustawie zawodowej działalności lobbingowej, a więc zarobkowej działalności wykonywanej na rzecz osób trzecich, z czego wynika, że zapisy te nie będą dotyczyły osób wykonujących działalność lobbingową we własnym imieniu i na swoją korzyść oraz osób wykonujących swoje działania w celu niezarobkowym. Ustawa w art. 19. określa także jedną i jedyną sytuację, która uzasadnia nałożenie kary na lobbystę. Sytuacją tą jest wykonywanie czynności wchodzących w zakres zawodowej działalności lobbingowej bez wpisu do rejestru. Takie postępowanie podlega karze pieniężnej w wysokości od 3.000 zł do 50.000 zł. Przepisy określające zarówno sytuację uzasadniającą nałożenie kary, jak i jej formę oraz rozmiar są bez wątpienia pobłażliwe.

Należy podkreślić, że regulacja wynikająca z omawianej ustawy dotyczy przede wszystkim zdefiniowanej w niej zawodowej działalności lobbingowej. Dzięki tej ustawie dysponujemy więc z jednej strony ewidencją prac organów władzy publicznej oraz ewidencją zawodowych lobbystów. Ustawa ta zmusza także organy władzy publicznej do określenia procedur zachowania się względem osób wykonujących zawodową działalność lobbingową. Ustawa stwarza także rejestry działań zawodowego lobbingu w postaci odpowiednich wzmianek w Biuletynie Informacji Publicznej oraz corocznych informacji tworzonych przez organy władzy publicznej. Wprowadza także dotyczącą wszystkich obywateli instytucję wysłuchania publicznego.

Jaka jest więc ta ustawa? Aby odpowiedzieć sobie na to pytanie, trzeba przypomnieć sobie jej cele, przedmiot regulacji oraz intencje jej stworzenia. Należy stwierdzić, że omawiana ustawa jest błaha i infantylna, nie reguluje w żaden istotny oraz pożądany sposób zjawiska wpływania grup interesów na proces stanowienia prawa. Nie zmienia także poziomu świadomości obywateli dotyczącego stanowienia prawa, grup interesów. Nakłada obowiązki (poza jednym - wpisaniem do rejestru) wyłącznie na organy władzy. Charakter wszystkich obowiązków jest „statystyczno-urzędniczy” i nie ma żadnego wpływu na realne działania, do czego przyczyniło się także wyróżnienie zawodowej dzia- 
łalności lobbingowej. Ustawa ta stanowi przykład tego, że porządek w administracji degraduje się do porządku w dokumentach, które razem z instytucjami odrywają się od rzeczywistości ${ }^{15}$. Ustawa miała kontrolować działalność lobbingową w procesie stanowienia prawa, ale tak naprawdę mogłaby wcale nie obowiązywać, nie zmieniając tym w niczym obrazu funkcjonowania grup interesu. W świetle przedstawionej koncepcji społeczeństwa odpowiedzialnego oraz zgodnie z socjocybernetycznym ujęciem społeczeństwa należy negatywnie ocenić przedmiotową ustawę jako przykład braku odpowiedzialności.

\section{Bibliografia}

Batorski D., Kapitał społeczny i otwartość jako podstawa innowacyjności, https://www. academia.edu/2939443/Kapital_spoleczny_i_otwartosc_jako_podstawa_innowacyjnosci (30.06.2014).

Czapiński J., Kapitał ludzki i kapitał społeczny a dobrobyt materialnyo. Polski paradoks, http://www.msap.uek.krakow.pl/doki/publ/Zarzadzanie_Publiczne_2008_2-4.pdf (30.06.2014).

Działocha K., Trzciński J., Wójtowicz K., Studia nad udziałem grup interesów w procesie tworzenia prawa, Wrocław 1987.

Friedman M., Friedman R., Tyrania status quo, Sosnowiec 1997.

Grupy interesu. Teorie i działanie, red. Z. Machelski, L. Rubisz, Toruń 2003.

Hayek von F. A., Nadużycie rozumu, Warszawa 2002.

Kossecki J., Cybernetyka kultury, Warszawa 1974.

Stelmach J., Brożek B., Załuski W., Dziesięć wykładów o ekonomii prawa, Warszawa 2007.

15 J. Kossecki, Cybernetyka kultury, dz. cyt., s. 61. 